\title{
EFEKTIVITAS PEMBELAJARAN KOOPERATIF TIPE STUDENT TEAMS ACHIEVEMENT DIVISIONS (STAD) TERHADAP KEMANDIRIAN DAN PRESTASI BELAJAR PESERTA DIDIK PADA MATERI PERANGKAT LUNAK PENGOLAH ANGKA
}

\author{
Epi Yulistina $^{1)}$, Milah Nurkamilah ${ }^{2)}$, Sulidar Fitri ${ }^{3)}$ \\ 1,2,3) Pendidikan Teknologi Informasi, FKIP Universitas Muhammadiyah Tasikmalaya \\ email : yulistinaevi49@gmail.com ${ }^{1)}$, milah.nurkamilah@umtas.ac.id ${ }^{2}$, sfitri@umtas.ac.id ${ }^{3}$
}

\begin{abstract}
ABSTRAKSI
Kemandirian belajar peserta didik menjadi hal yang penting dan perlu dicapai dalam sebuah proses pendidikan karena salah satunya diduga akan berdampak pada pencapaian prestasi belajar. Penelitian ini bertujuan untuk mengetahui efektivitas pembelajaran kooperatif tipe Student Teams-Achievment Divisons (STAD) terhadap kemandirian dan prestasi belajar pada materi perangkat lunak pengolah angka, serta untuk mengetahui hubungan antara kemandirian dan prestasi belajar peserta didik. Penelitian ini merupakan penelitian eksperimen yang dilaksanakan di SMK BPI Baturompe kota Tasikmalaya dengan populasi kelas X BDPM. Sampel penelitian dilakukan dengan teknik Simple Random Sampling. Teknik pengumpulan data menggunakan metode non tes dan tes. Instrumen yang digunakan berupa angket kemandirian belajar, dokumentasi dan soal tes prestasi belajar. Hasil penelitian menunjukkan (1) Nilai uji t post test angket kemandirian belajar 7,953 > t tabel 2,02. (2) Nilai uji t post test prestasi belajar 3,990 > t tabel 2,02. (3) Uji korelasi antara kemandirian dan prestasi belajar peserta didik nilai $r$ hitung 0,730 > r tabel 0,433 dengan nilai signifikansi 0,000. Dengan demikian model pembelajaran kooperatif tipe STAD efektif terhadap kemandirian dan prestasi belajar serta terdapat hubungan antara kemandirian belajar dengan prestasi belajar peserta didik dengan tingkat hubungan berada pada kategori kuat.
\end{abstract}

Kata Kunci : STAD, Kemandirian Belajar, Prestasi Belajar, Perangkat Lunak Pengolah Angka

\begin{abstract}
The independence learning of students are important and need to be achieved in an educational process because one of them gives impact on learning achievement. The purpose of this research is to know the effectiveness of cooperative learning Students Teams type-Achievement Divisons (STAD) on independence and learning achievement in subject processing software material, and to know the relationship between independence and students achievement. This research is an experimental research at SMK BPI Baturompe, Tasikmalaya City with a population of class X BDPM. Sample In this research is using the simple random sampling technique. Technique of collecting the data is using non-test and test methods. The instrument used in this research is a learning independence questionnaire, documentation and learning achievement test questions. The results show (1) The value of the post-test t test for the independent learning questionnaire was 7.953>t table 2.02. (2) The post-test t-test score of learning achievement was 3,990> t table 2,02. (3) Test the correlation between independence and students achievement with a value of $r$ count $0.730>r$ table 0.433 with a significance value of 0.000 . Thus the type of STAD cooperative learning model is effective on independence and learning achievement and there is a relationship between independence learning and students learning achievement with the relationship level in strong category.
\end{abstract}

Keywords : STAD, Independent Learning, Learning Achievement, Number Processing Software.

\section{PENDAHULUAN}

Undang-Undang Nomor 20 Tahun 2003 tentang Sistem Pendidikan Nasional pasal 3 mengamanatkan pengembangan kemampuan dan membentuk manusia Indonesia yang bermartabat dalam rangka mencerdaskan kehidupan bangsa. Pendidikan juga bertujuan untuk mengembangkan potensi peserta didik agar menjadi manusia yang beriman dan bertakwa kepada Tuhan Yang Maha Esa, berakhlak mulia, berilmu, kreatif, menjadi warga Negara yang demokratis, bertangung jawab serta mandiri. Berdasarkan regulasi tersebut, kemandirian menjadi hal yang penting dan perlu dicapai dalam sebuah proses pendidikan. Kemandirian dalam proses pendidikan merupakan sebuah perilaku dimana peserta didik percaya akan kemampuan dirinya sendiri tanpa bergantung pada orang lain.

Berdasarkan hasil observasi awal pada kegiatan belajar mengajar pada mata pelajaran Simulasi dan Komunikasi Digital di SMK BPI Baturompe Kota Tasikmalaya, teridentifikasi peserta didik yang masih pasif 
dalam mengikuti proses pembelajaran. Pada saat melakukan observasi metode yang digunakan guru masih menggunakan metode ceramah sehingga diduga menimbulkan kegiatan pembelajaran yang monoton, bahkan masih terdapat peserta didik yang tidak memperhatikan saat guru sedang menjelaskan materi pelajaran. Hal ini menunjukkan bahwa kemandirian peserta didik masih kurang dan diduga mengakibatkan prestasi belajar peserta didik kurang optimal

Data hasil ulangan belajar peserta didik pada Kompetensi Dasar (KD) Menerapkan Logika dan Operasi Perhitungan data tahun terakhir memperlihatkan bahwa 58 peserta didik $(78,38 \%)$ mendapatkan nilai di bawah Kriteria Ketuntasan Minimal (KKM) dan hanya 16 peserta didik (21,62\%) yang mendapatkan nilai mencapai atau melampaui KKM, sedangkan mata pelajaran Simulasi dan Komunikasi Digital merupakan salah satu mata pelajaran pada Sekolah Menengah Kejuruan (SMK) yang diharapkan dapat menjadi dasar life skill yang harus dikuasai oleh peserta didik. Oleh karena itu, diperlukan tindakan untuk memperbaiki proses pembelajaran yang bisa membuat kemandirian peserta didik lebih berkembang untuk memperoleh prestasi belajar yang lebih optimal.

Salah satu upaya yang dapat digunakan untuk mengembangkan kemandirian dan prestasi belajar peserta didik adalah dengan cara pemilihan model pembelajaran yang tepat, salah satunya menggunakan model pembelajaran kooperatif tipe Student Teams-Achievment Divisons (STAD). STAD terdiri atas lima komponen utama yaitu presentasi kelas, kerja kelompok, kuis, skor kemajuan individual dan penghargaan kelompok [9]. STAD juga merupakan pembelajaran kooperatif yang sangat sederhana dibandingkan dengan pembelajaran kooperatif yang lain.

Hasil penelitian yang telah dilakukan oleh Wisnu Murti Pratama dkk dalam jurnal yang berjudul Penerapan Metode Pembelajaran Student Teams Achievement Division (STAD) Dilengkapi Media Log Book Chesmistry (Logchem) untuk Meningkatkan Kemandirian dan Prestasi Belajar Peserta didik pada materi Koloid Kelas KIMIA SMAN 1 Banyudono Tahun Pelajaran 2014/2015 menunjukan bahwa model pembelajaran yang menerapkan tipe STAD terbukti efektif meningkatkan kemandirian dan prestasi belajar peserta didik [12].

Berdasarkan uraian di atas peneliti tertarik melakukan penelitan tentang efektivitas pembelajaran kooperatif tipe Student Teams Achievment Divisions (STAD) terhadap kemandirian dan prestasi belajar peserta didik pada materi perangkat lunak pengolah angka.

Penelitian ini bertujuan untuk mendeskripsikan dan menguji efektivitas penerapan pembelajaran kooperatif tipe Student Teams Achievment Divisions (STAD) terhadap kemandirian dan prestasi belajar pada materi Perangkat Lunak Pengolah Angka serta untuk engetahui hubungan antara kemandirian dan prestasi belajar peserta didik dalam mencapai efektivitas.

\section{Efektivitas Pembelajaran Kooperatif Tipe STAD}

STAD merupakan salah satu model pembelajaran kooperatif dengan menggunakan kelompok-kelompok kecil dengan jumlah anggota tiap kelompok empat sampai lima orang peserta didik secara heterogen. Pembelajaran ini diawali dengan presentasi kelas (penyajian materi), kegiatan kelompok, kuis, penghargaan individu, dan penghargaan kelompok.

Arends menyatakan bahwa pada STAD peserta didik di kelas dibagi menjadi beberapa kelompok kecil yang merupakan campuran menurut tingkat prestasi, jenis kelamin, dan suku. Guru menyajikan pelajaran kemudian peserta didik bekerja dalam tim mereka memastikan bahwa seluruh anggota tim telah menguasai pelajaran tersebut [1].

Kelebihan pembelajaran kooperatif Tipe STAD menurut Kristanto antara lain:

a. menumbuhkan rasa percaya diri dan meningkatkan kecakapan individunya

b. Peserta didik memiliki dua bentuk tanggung jawab belajar, yaitu belajar untuk dirinya sendiri dan membantu sesama anggota kelompok untuk belajar atau pembelajaran oleh rekan sebaya

c. Pengelompokan peserta didik secara heterogen membuat kompetisi yang terjadi di kelas menjadi lebih hidup.

d. Pemberian kuis bisa meningkatkan tanggung jawab individu, karena nilai akhir kelompok dipengaruhi nilai kuis yang dikerjakan secara individu.

e. Peserta didik untuk saling memotivasi, saling membantu satu sama lain dalam menguasai pelajaran guna mencapai hasil belajar yang maksimal.

Sedangkan kekurangan pembelajaran kooperatif Tipe STAD antara lain:

a. Membutuhkan waktu yang relatif lama, dengan memperhatikan tahapan STAD seperti penyajian materi dari guru, kerja kelompok dan tes individual/kuis. Namun penggunaan waktu yang lebih lama ini dapat sedikit diminimalisir saat pembentukan kelompok saat sebelum kegiatan pembelajaran dilaksanakan. Dengan demikian, dalam kegiatan pembelajaran tidak ada waktu yang terbuang untuk pembentukan kelompok.

b. Pembelajaran kooperatif tidak terkecuali STAD, bila tidak dipersiapkan dan dirancang dengan baik dan benar dapat menimbulkan hal-hal yang tidak diinginkan misalnya sebagian anggota kelompok melakukan semua atau sebagian besar dari seluruh pekerjaan sementara yang lainya hanya diam. Untuk meminimalisir masalah tersebut maka guru perlu menjelaskan dan memberikan pemahaman tentang penilaian dalam pembelajaran tipe STAD ini. Peserta didik perlu di tanamkan rasa tanggung jawab dan jiwa berkompetisi antar kelompok. Apabila menginginkan kelompoknya menjadi juara atau yang terbaik maka seluruh anggota kelompok harus turut 
berperan dalam tugas-tugas kelompok dan memahami semua materi pembelajaran, karena nilai kuis yang dikerjakan secara individu menentukan nilai akhir kelompok.

c. Jika guru tidak bisa mengarahkan anak, maka anak yang berprestasi bisa jadi lebih dominan dan tak terkendali didalam kelompok. Lalu karena tidak adanya kompetisi diantara anggota masing-masing kelompok, bisa saja anak yang berprestasi menurun semangatnya [5].

Pembelajaran kooperatif tipe STAD dikatakan efektif jika rata-rata kelas eksperimen lebih baik dari kelas kontrol, hal ini sesuai dengan pandangan Uno dan Mohamad dalam jurnal Layinatussifa yang mengemukakan bahwa efektivitas pembelajaran ditujukan untuk menjawab pertanyaan seberapa jauh tujuan pembelajaran telah dicapai oleh peserta didik dimana suatu metode dapat dikatakan efektif dalam mencapai tujuan pembelajaran apabila metode tersebut dibanding dengan metode lain dapat mencapai tujuan lebih besar [6]. Sedangkan menurut Rusman dalam Fathurrahman dkk mengemukakan bahwa pembelajaran dapat dikatakan efektif apabila mampu memberikan pengalaman baru dan dapat membentuk kompetensi siswa serta membantu mencapai tujuan secara optimal [3].

2. Kemandirian Belajar

Menurut Rachmayani kemandirian adalah perilaku peserta didik dalam mewujudkan kehendak atau keinginannya secara nyata dengan tidak bergantung pada orang lain, dalam hal ini peserta didik mampu melakukan belajar sendiri, dapat menentukan cara belajar yang efektif, mampu melaksanakan tugas belajar dengan baik dan mampu untuk melakukan aktivitas belajar secara mandiri [8].

Menurut Suptiyati belajar mandiri adalah kegiatan belajar aktif, yang didorong oleh niat atau motif untuk menguasai suatu kompetensi guna mengatasi suatu masalah, dan dibangun dengan bekal pengetahuan atau kompetensi yang dimiliki. Pencapaian kompetensi sebagai tujuan beiajar, dan cara penyampaiannya baik penetapan waktu belajar, tempat belajar, tempo belajar, cara belajar, maupun evaluasi belajar dilakukan oleh peserta didik sendiri. Disini belajar mandiri lebih dimaknai sebagai usaha peserta didik untuk melakukan kegiatan belajar yang didasari niat untuk menguasai suatu kompetensi tertentu [10].

3. Prestasi Belajar

Suryabrata menyatakan bahwa prestasi belajar adalah hasil yang dicapai dari hasil latihan, pengalaman yang didukung oleh kesadaran. Jadi prestasi belajar merupakan hasil dari perubahan dalam proses belajar [11]. Sedangkan menurut Nasution menyatakan bahwa prestasi belajar adalah kesempumaan yang dicapai seseorang dalam berfikir, merasa dan berbuat. Prestasi belajar dikatakan sempurna apabila memenuhi tiga aspek yaitu kognitif, afektif dan psikomotor, sebaliknya dikatakan kurang memuaskan apabila belum mampu memenuhi target ketiga kategori tersebut [7].

Berdasarkan pengertian di atas dapat disimpulkan bahwa prestasi belajar adalah merupakan tingkat keberhasilan dalam proses pembelajaran setelah melalui tahap tes yang dinyatakan dalam bentuk nilai berupa angka. Prestasi belajar dapat diketahui setelah melakukan evaluasi dan evaluasi dapat memperlihatkan tentang tinggi atau rendahnya prestasi belajar.

\section{METODE PENELITIAN}

Penelitian ini menggunakan bentuk metode eksperimen dengan pendekatan Quasi Eksperimental dengan desain Non-equivalent Control Group Design. Rancangan desain penelitian, terdiri dari dua kelompok yaitu kelompok eksperimen dan kelompok kontrol. Sebelum diberikan perlakuan, terlebih dahulu diberikan pre test untuk melihat kemampuan awal masing-masing kelompok. Kemudian kelas eksperimen diberi treatment dengan menggunakan model pembelajaran kooperatif tipe STAD sedangkan kelas kontrol diberi perlakuan dengan menggunakan metode ceramah, dan setelah itu diberikan post test untuk melihat adanya perbedaan kemandirian dan prestasi belajar antara kedua kelompok yang dapat dilihat dalam bentuk tabel 1 berikut:

Tabel 1. Desain Penelitian

\begin{tabular}{|l|c|c|c|}
\hline \multicolumn{1}{|c|}{ Kelompok } & Pre-test & Treatment & Post-test \\
\hline Kelas eksperimen & $\mathrm{O}_{1}$ & $\mathrm{X}_{1}$ & $\mathrm{O}_{2}$ \\
\hline Kelas kontrol & $\mathrm{O}_{3}$ & $\mathrm{X}_{2}$ & $\mathrm{O}_{4}$ \\
\hline
\end{tabular}

\section{Keterangan :}

A $\quad=$ Kelas eksperimen

$\mathrm{B} \quad=$ Kelas kontrol

$\mathrm{X}_{1} \quad=$ Perlakuan dengan metode tipe STAD

$\mathrm{X}_{2} \quad=$ Perlakuan dengan metode ceramah

$\mathrm{O}_{1} \& \mathrm{O}_{3}=$ Pre test (kelas eksperimen dan kontrol sebelum perlakuan)

$\mathrm{O}_{2} \& \mathrm{O}_{4}=$ Post test (kelompok eksperimen dan kontrol setelah perlakuan)

Penelitian ini dilaksanakan di SMK BPI Baturompe Tasikmalaya Jln. Cigantang Hilir No. 115-117 Kelurahan Cigantang Kecamatan Mangkubumi Kota Tasikmalaya pada semester ganjil tahun pelajaran 2020-2021, dengan 
populasi peserta didik kelas X Bisnis Daring dan Pemasaran(BDPM) berjumlah 42 orang. Teknik pengambilan sampel dilakukan dengan menggunakan teknik Simple random sampling. Sampel untuk kelas eksperimen yaitu kelas X BDPM 1 dengan jumlah peserta didik sebanyak 21 orang sedangkan kelas kontrol yaitu kelas X BDPM 2 yang berjumlah 21 orang. Adapun variabel bebas dalam penelitian ini adalah model pembelajaran kooperatif tipe STAD dan metode ceramah sedangkan variabel terikat dalam penelitian ini yaitu kemandirian belajar dan prestasi belajar peserta didik pada materi perangkat lunak pengolah angka.

Teknik pengumpulan data yang digunakan dalam penelitian ini berupa non tes dan tes. Non tes digunakan untuk mengukur kemandirian belajar peserta didik dengan menggunakan instrumen kuesioner atau angket, dan dokumentasi untuk memperkuat dan memperjelas data antara lain berupa silabus dan RPP mata pelajaran Simulasi dan Komunikasi Digital, data peserta didik serta data hasil belajar peserta didik. Sedangkan tes merupakan alat atau prosedur yang digunakan untuk mengetahui atau mengukur sesuatu dalam suasana, dengan cara dan aturanaturan yang sudah ditentukan yaitu berupa tes prestasi belajar. Tes yang baik adalah tes yang valid, reliabel dan mudah untuk dilaksanakan. Dalam penelitian ini validitas tes menggunakan validitas isi sedangkan reliabilitas tes menggunakan perhitungan Alpha Cronbach dimana sebuah instrumen akan dikatakan reliabel apabila Indeks Alpha $>0,05$. Hasil perhitungan Indeks Alpha angket kemandirian belajar $=0,791>0,05$, sedangkan untuk instrumen soal tes menunjukkan hasil 0,734 >0,05 artinya instrumen kemandirian belajar dan soal tes prestasi belajar reliabel dan dapat dipergunakan.

Teknik Analisis Data yang digunakan meliputi statistik deskriptif, uji hipotesis dan korelasi product moment. Statistik deskriftif digunakan untuk mengetahui nilai ketercapaian penerapan metode pembelajaran kooperatif tipe STAD terhadap perkembangan kemandirian dan prestasi belajar peserta didik pada mata pelajaran simulasi dan komunikasi digital. Sedangkan uji hipotesis menggunakan Uji Independent Sampel t-tes yang bertujuan untuk membandingkan perbedaan kelompok kontrol dan kelompok eksperimen sebelum dan sesudah dilakukan treatment atau perlakuan dan Uji Korelasi Product Moment digunakan untuk mencari hubungan antara kemandirian belajar dan prestasi belajar peserta didik.

\section{HASIL DAN PEMBAHASAN}

\section{Hasil Penelitian}

1. Hasil Pre Test dan Post Test

a. Hasil Pre Test dan Post Test Kemandirian Belajar

Untuk melihat perkembangan kemandirian belajar peserta didik peneliti menggunakan instrumen non tes berupa pre test dan post test angket kemandirian belajar yang diberikan sebelum dan sesudah pemberian perlakuan. Pre test dan post test angket kemandirian belajar diberikan kepada kelas eksperimen maupun kelas kontrol. Berikut hasil analisis nilai data pre test - post test angket kemandirian belajar peserta didik kelas eksperimen yang disajikan pada tabel 2 berikut ini:

Tabel 2. Rekapitulasi Hasil nilai rata-rata Pre test - Post test kemandirian belajar kelas eksperimen

\begin{tabular}{|l|l|c|c|}
\hline No & \multicolumn{1}{|c|}{ Keterangan } & Skor & Kategori \\
\hline 1. & Nilai rata-rata pre test kemandirian belajar kelas & 2,1 & Kurang \\
\hline 2. & Nilai rata-rata post test kemandirian belajar kelas & 3,0 & Baik \\
\hline
\end{tabular}

Dari tabel 2 dapat diketahui bahwa nilai rata-rata kemandirian belajar peserta didik kelas eksperimen sebelum dan sesudah diberikan treatment mengalami peningkatan, dimana nilai rata-rata kemandirian belajar secara keseluruhan sebelum diberikan treatment berada pada nilai 2,1 dengan kategori kurang, dan setelah diberikan treatment berupa penerapan model pembelajaran kooperatif tipe STAD nilai rata-rata kemandirian belajar peserta didik kelas eksperimen berada pada kategori baik dengan nilai rata-rata 3,0. Sebagai perbandingan berikut hasil analisis data pre test - post test angket kemandirian belajar peserta didik kelas kontrol yang disajikan pada tabel 3:

Tabel 3. Rekapitulasi Hasil Nilai Rata-rata Pre test - Post test Kemandirian Belajar Kelas Kontrol

\begin{tabular}{|c|l|c|c|}
\hline No & \multicolumn{1}{|c|}{ Keterangan } & Kategori & Kategori \\
\hline 1. & $\begin{array}{l}\text { Nilai rata-rata pre test kemandirian belajar kelas } \\
\text { kontrol }\end{array}$ & 2,0 & Kurang \\
\hline 2. & $\begin{array}{l}\text { Nilai rata-rata post test kemandirian belajar kelas } \\
\text { kontrol }\end{array}$ & 2,2 & Kurang \\
\hline
\end{tabular}

Dari tabel 3 dapat diketahui bahwa nilai rata-rata kemandirian belajar peserta didik kelas kontrol sebelum dan sesudah diberikan treatment tidak terlalu mengalami peningkatan, dimana nilai rata-rata kemandirian belajar secara keseluruhan sebelum diberikan treatment berada pada nilai 2,0 dengan kategori kurang, dan setelah diberikan treatment berupa penerapan model pembelajaran dengan metode ceramah nilai rata-rata kemandirian belajar peserta didik kelas kontrol masih berada pada kategori kurang dengan nilai rata-rata menjadi 2,2. 


\section{b. Hasil Pre Test dan Post Test Prestasi Belajar}

Prestasi belajar peserta didik setelah menggunakan pembelajaran tipe STAD mengalami peningkatan. Hal ini diketahui dari hasil analisis data soal pre test dan post test prestasi belajar. Berdasarkan hasil analisis data soal pre test, nilai rata-rata kelas eksperimen berada di kategori sangat kurang dan tidak ada peserta didik yang tuntas atau mendapat nilai yang mencapai $\mathrm{KKM}=70$, dan setelah diberikan treatment nilai rata-rata kelas eksperimen berada di kategori baik. Berikut hasil analisis data pre test-post test kelas eksperimen yang dapat dilihat pada tabel 4:

Tabel 4. Hasil Pre Test - Post Test Prestasi Belajar Kelas Eksperimen

\begin{tabular}{|c|l|c|c|}
\hline No & \multicolumn{1}{|c|}{ Keterangan } & \multicolumn{1}{|c|}{$\begin{array}{c}\text { Pre test kelas } \\
\text { eksnerimen }\end{array}$} & $\begin{array}{c}\text { Post test kelas } \\
\text { eksnerimen }\end{array}$ \\
\hline 1 & Nilai tertinggi & 40 & 85 \\
\hline 2 & Nilai terendah & 5 & 40 \\
\hline 3 & Nilai rata-rata & 19 & 71 \\
\hline 4 & Jumlah peserta didik & \multicolumn{2}{|c|}{21} \\
\hline 5 & Presentase jumlah peserta didik & $0 \%$ & $67 \%$ \\
\hline 6 & $\begin{array}{l}\text { Presentase jumlah peserta didik } \\
\text { tidak tuntas }\end{array}$ & $100 \%$ & $33 \%$ \\
\hline
\end{tabular}

Dari tabel 4 dapat dilihat nilai pre test kelas eksperimen dengan jumlah 21 peserta didik, nilai tertinggi 40, nilai terendah 5 dan nilai rata-rata 19 yang berada pada kategori sangat kurang dengan pencapaian presentase jumlah peserta didik yang tuntas atau memenuhi KKM sebanyak 0\% yang artinya tidak ada peserta didik yang mengerjakan secara tuntas dan setelah diberikan treatment berupa penerapan pembelajaran kooperatif tipe STAD nilai prestasi belajar yang dapat dilihat dari nilai post test mengalami peningkatan, nilai tertinggi 85 , nilai terendah 40 dan nilai rata-rata 71 berada pada kategori baik, dengan pencapaian presentase jumlah peserta didik yang tuntas sebanyak $67 \%$. Sebagai perbandingan berikut hasil pre test - post test prestasi belajar kelas kontrol dapat di lihat dari tabel 5:

Tabel 5. Hasil Pre Test - Post Test Prestasi Belajar Kelas Kontrol

\begin{tabular}{|c|l|c|c|}
\hline No & \multicolumn{1}{|c|}{ Keterangan } & $\begin{array}{c}\text { Pre test kelas } \\
\text { kontrol }\end{array}$ & $\begin{array}{c}\text { Post test kelas } \\
\text { kontrol }\end{array}$ \\
\hline 1 & Nilai tertinggi & 35 & 75 \\
\hline 2 & Nilai terendah & 5 & 30 \\
\hline 3 & Nilai rata-rata & 17 & 55 \\
\hline 4 & Jumlah peserta didik & \multicolumn{2}{|c|}{21} \\
\hline 5 & Presentase jumlah peserta didik & $0 \%$ & $29 \%$ \\
\hline 6 & Presentase jumlah peserta didik & $100 \%$ & $71 \%$ \\
\hline
\end{tabular}

Dari tabel 5 dapat dilihat hasil pre test prestasi belajar kelas kontrol dengan jumlah 21 peserta didik, nilai tertinggi 35, nilai terendah 5, dan nilai rata-rata 17 yang berada pada kategori sangat kurang dengan pencapaian presentase jumlah peserta didik yang tuntas atau memenuhi KKM sebanyak 0\% yang artinya tidak ada peserta didik yang mengerjakan secara tuntas dan setelah diberikan treatment berupa penerapan pembelajaran dengan metode konvesional dapat dilihat dari nilai post test prestasi belajar kelas kontrol, nilai tertinggi 75, nilai terendah 30, dan nilai rata-rata 55 berada pada kategori cukup dengan jumlah peserta didik yang tuntas sebanyak $29 \%$ dan peserta didik yang tidak tuntas sebanyak $71 \%$.

\section{Hasil Uji Hipotesis Kemandirian Belajar}

Analisis data uji hipotesis kemandirian belajar dihitung dengan menggunakan uji independent sampel t-tes. Untuk menghitung uji independent sampel t-tes maka diperlukan uji normalitas dan uji homogenitas terlebih dahulu. Dan berikut perhitungan uji normalitas dan uji homogenitas pre test - post test kemandirian belajar a. Uji Normalitas

Uji normalitas yang dilakukan dalam penelitian ini menggunakan uji Shapiro wilk dengan taraf signifikan 5\% karena sampel penelitian berjumlah 42 orang (kurang dari 100) dengan kriteria jika nilai signifikan $(\operatorname{sig})>0,05$ maka Ho diterima sedangkan jika nilai signifikan $(\mathrm{sig})<0,05$ maka Ha ditolak. Adapun hasil dari uji normalitas post test kemandirian belajar baik di kelas eksperimen maupun kelas kontrol dapat dilihat pada tabel 6: 
Tabel 6. Uji Normalitas Post Test Kemandirian Belajar

\begin{tabular}{|l|c|c|}
\hline \multicolumn{1}{|c|}{ Variabel } & Sig. Shapiro-Wilk & Keterangan \\
\hline $\begin{array}{l}\text { Post test kemandirian belajar kelas } \\
\text { eksperimen }\end{array}$ & 0,444 & Data berdistribusi normal \\
\hline Post test kemandirian belajar kelas kontrol & 0,364 & Data berdistribusi normal \\
\hline
\end{tabular}

Dari hasil perhitungan uji normalitas post test kemandirian belajar pada tabel 6 dapat disimpulkan bahwa nilai signifikansi Shapiro-Wilk post test kemandirian belajar kelas eksperimen 0,444 > 0,05 dan nilai signifikansi Shapiro-Wilk post test kemandirian belajar kelas kontrol 0,364 >0,05 sehingga dapat disimpulkan bahwa kedua data baik di kelas eksperimen maupun di kelas kontrol merupakan data berdistribusi normal

b. Uji Homogenitas

Uji homogenitas ini menggunakan statistik uji Levene dengan mengambil taraf signifikansi 5\% dengan kriteria jika nilai signifikansi (sig) $<0,05$ maka data berasal dari populasi yang mempunyai varians tidak homogen sedangkan jika nilai signifikansi (sig) $>0,05$ maka data berasal dari populasi yang mempunyai varians homogen. Berikut hasil uji homogenitas post test kemandirian belajar pada kelas eksperimen dan kelas kontrol yang disajikan dalam bentuk tabel 7:

Tabel 7. Uji Homogenitas Post Test Kemandirian Belajar

\begin{tabular}{|l|c|c|l|}
\hline \multicolumn{1}{|c|}{ Variabel } & $\begin{array}{c}\text { Levene } \\
\text { Statistic }\end{array}$ & \multicolumn{1}{|c|}{ Sig. } & \multicolumn{1}{|c|}{ Keterangan } \\
\hline $\begin{array}{l}\text { Post test kemandirian belajar kelas eksperimen dan } \\
\text { kelas kontrol }\end{array}$ & 0,010 & 0,922 & $\begin{array}{l}\text { Data berdistribusi } \\
\text { homogen }\end{array}$ \\
\hline
\end{tabular}

Dari hasil perhitungan uji homogenitas pada tabel 7 dapat disimpulkan bahwa nilai Levene Statistic post test kemandirian belajar kelas eksperimen dan kelas kontrol adalah 0,010 dengan nilai signifikansi 0,922 >0,05 yang artinya data berasal dari populasi yang mempunyai varians homogen.

c. Hasil uji Independent Sampel t-tes kemandirian belajar

Uji independent sampel t-tes ini digunakan untuk membandingkan perbedaan kelompok kontrol dan kelompok eksperimen sebelum dan sesudah dilakukan treatment atau perlakuan. Adapun rumusan hipotesis statistiknya dinyatakan sebagai berikut:

$\mathrm{H}_{\mathrm{o}}$ : Model pembelajaran kooperatif tipe Student Teams Achievment Divisions (STAD) tidak efektif terhadap kemandirian belajar peserta didik pada materi perangkat lunak pengolah angka

$\mathrm{H}_{\mathrm{a}}$ : Model pembelajaran kooperatif tipe Student Teams Achievment Divisions (STAD) efektif terhadap kemandirian belajar peserta didik pada materi perangkat lunak pengolah angka

Taraf signifikan yang digunakan adalah $5 \%(\mathrm{a}=0,05)$ dengan kriteria pengujian $\mathrm{H}_{\mathrm{o}}$ ditolak Jika $\mathrm{t}_{\text {hitung }} \geq$ $t_{\text {tabel }}$. Berikut hasil perhitungan uji independent sampel t-tes post test kemandirian belajar yang disajikan pada tabel 8:

Tabel 8. Uji Independent Sampel T-tes Post Test Kemandirian Belajar

\begin{tabular}{|c|c|c|c|c|c|}
\hline \multicolumn{1}{|c|}{ Variabel } & $\begin{array}{c}\text { Nilai t } \\
\text { hitung }\end{array}$ & $\begin{array}{c}\text { Sig. (2- } \\
\text { Tailed) }\end{array}$ & Df & $\begin{array}{c}\text { Nilai t } \\
\text { tabel }\end{array}$ & Keterangan \\
\hline $\begin{array}{l}\text { Post test } \text { kemandirian belajar kelas } \\
\text { eksperimen dan kelas kontrol }\end{array}$ & 7,953 & 0,000 & 40 & 2,02 & $\mathrm{H}_{\mathrm{o}}$ ditolak \\
\hline
\end{tabular}

Dari data pada tabel 8 nilai t hitung sebesar 7,953> 2,02 dengan nilai signifikansi 0,000, yang artinya $\mathrm{H}_{\mathrm{o}}$ ditolak dan $\mathrm{H}_{\mathrm{a}}$ diterima. Dengan demikian rata-rata kelas eksperimen lebih baik dari rata-rata kelas kontrol, maka dapat disimpulkan model pembelajaran kooperatif tipe Student Teams Achievment Divisions (STAD) efektif terhadap kemandirian belajar peserta didik pada materi perangkat lunak pengolah angka

4. Hasil Uji Hipotesi Prestasi Belajar

Uji hipotesis prestasi belajar menggunakan rumus uji independent sampel t-tes dilakukan untuk membandingkan perbedaan kelompok kontrol dan kelompok eksperimen sebelum dan sesudah dilakukan treatment atau perlakuan. Berikut perhitungan uji independent sampel t-tes pre test prestasi belajar.

a. Uji Normalitas

Adapun hasil dari uji normalitas post test kemandirian belajar baik di kelas eksperimen maupun kelas kontrol terlihat pada tabel 9 berikut ini:

Tabel 9. Uji Normalitas Post Test Prestasi Belajar

\begin{tabular}{|c|c|l|}
\hline Variabel & Sig. Shapiro-Wilk & \multicolumn{1}{|c|}{ Keterangan } \\
\hline Post test prestasi belajar kelas eksperimen & 0,062 & $\begin{array}{l}\text { Data berdistribusi } \\
\text { normal }\end{array}$ \\
\hline
\end{tabular}




\begin{tabular}{|l|c|l|}
\hline Post test prestasi belajar kelas kontrol & 0,193 & $\begin{array}{l}\text { Data berdistribusi } \\
\text { normal }\end{array}$ \\
\hline
\end{tabular}

Dari hasil perhitungan uji normalitas post test prestasi belajar pada tabel 9 dapat disimpulkan bahwa nilai signifikansi Shapiro-Wilk post test prestasi belajar kelas eksperimen 0,062 > 0,05 dan nilai signifikansi ShapiroWilk post test prestasi belajar kelas kontrol 0,193 > 0,05 sehingga dapat disimpulkan bahwa kedua data baik di kelas eksperimen maupun di kelas kontrol merupakan data berdistribusi normal

b. Uji Homogenitas

Adapun untuk hasil uji homogenitas post test prestasi belajar pada kelas eksperimen dan kelas kontrol dengan dapat dilihat pada tabel 10:

Tabel 10. Uji Homogenitas Post Test Prestasi Belajar

\begin{tabular}{|l|c|c|c|}
\hline \multicolumn{1}{|c|}{ Variabel } & $\begin{array}{c}\text { Levene } \\
\text { Statistic }\end{array}$ & Sig. & \multicolumn{1}{|c|}{ Keterangan } \\
\hline $\begin{array}{l}\text { Post test } \text { prestasi belajar kelas eksperimen dan kelas } \\
\text { kontrol }\end{array}$ & 2.610 & $.0,114$ & $\begin{array}{l}\text { Data berdistribusi } \\
\text { homogen }\end{array}$ \\
\hline
\end{tabular}

Dari hasil perhitungan uji homogenitas pada tabel 10 dapat disimpulkan bahwa nilai Levene Statistic post test prestasi belajar kelas eksperimen dan kelas kontrol adalah 0,326 dengan nilai signifikansi 0,114>0,05 yang artinya data berasal dari populasi yang mempunyai varians homogen.

c. Hasil uji Independent Sampel t-tes prestasi belajar

Uji independent sampel t-tes ini digunakan untuk membandingkan perbedaan kelompok kontrol dan kelompok eksperimen sebelum dan sesudah dilakukan treatment atau perlakuan. Adapun rumusan hipotesis statistiknya dinyatakan sebagai berikut:

$\mathrm{H}_{\mathrm{o}}$ : Model pembelajaran kooperatif tipe Student Teams Achievment Divisions (STAD) tidak efektif terhadap prestasi belajar peserta didik pada materi perangkat lunak pengolah angka

$\mathrm{H}_{\mathrm{a}}$ : Model pembelajaran kooperatif tipe Student Teams Achievment Divisions (STAD) efektif terhadap prestasi belajar peserta didik pada materi perangkat lunak pengolah angka

Taraf signifikan yang digunakan adalah $5 \%(\mathrm{a}=0,05)$ dengan kriteria pengujian $\mathrm{H}_{\mathrm{o}}$ ditolak Jika $\mathrm{t}_{\text {hitung }} \geq$ $\mathrm{t}_{\text {tabel}}$. Berikut merupakan hasil perhitungan uji independent sampel $t$-tes post test prestasi belajar yang disajikan dalam bentuk tabel 11:

Tabel 11. Uji Independent Sampel T-tes Post Test Prestasi Belajar

\begin{tabular}{|c|c|c|c|c|c|}
\hline Variabel & $\begin{array}{c}\text { Nilai t } \\
\text { hitung }\end{array}$ & $\begin{array}{c}\text { Sig. (2- } \\
\text { Tailed) }\end{array}$ & Df & $\begin{array}{c}\text { Nilai t } \\
\text { tabel }\end{array}$ & Keterangan \\
\hline $\begin{array}{l}\text { Post test prestasi belajar kelas } \\
\text { eksperimen dan kelas kontrol }\end{array}$ & 3,990 & 0,000 & 40 & 2,02 & $\mathrm{H}_{\mathrm{o}}$ ditolak \\
\hline
\end{tabular}

Dari tabel 11 nilai t hitung sebesar 3,990 > 2,02 dengan nilai signifikansi 0,000, yang artinya $\mathrm{H}_{\mathrm{o}}$ ditolak dan $\mathrm{H}_{\mathrm{a}}$ diterima. Dengan demikian rata-rata kelas eksperimen lebih baik dari rata-rata kelas kontrol, sehingga dapat disimpulkan model pembelajaran kooperatif tipe Student Teams Achievment Divisions (STAD) efektif terhadap prestasi belajar peserta didik pada materi perangkat lunak pengolah angka.

5. Hasil Uji Korelasi Product Moment

Uji korelasi digunakan untuk pengujian hipotesis hubungan kemandirian belajar peserta didik terhadap prestasi belajar peserta didik. Dengan rumusan hipotesisnya ditetapkan sebagai berikut :

$\mathrm{H}_{\mathrm{o}}$ : Tidak terdapat hubungan antara kemandirian belajar peserta didik dengan prestasi belajar peserta didik.

$\mathrm{H}_{\mathrm{a}}$ :Terdapat hubungan antara perkembangan kemandirian belajar peserta didik dengan prestasi belajar peserta didik.

dengan taraf signifikan yang digunakan adalah $5 \%(a=0,05)$ dengan kriteria pengujiannya sebagai berikut:

a) Jika $r_{\text {hitung }}<r_{\text {tabel }}$ maka $\mathrm{H}_{\mathrm{o}}$ diterima dan $\mathrm{H}_{\mathrm{a}}$ ditolak

b) Jika $r_{\text {hitung }}>t_{\text {tabel }}$ maka $\mathrm{H}_{\mathrm{o}}$ ditolak dan $\mathrm{H}_{\mathrm{a}}$ diterima

Berikut hasil uji korelasi Product Moment yang disajikan pada tabel 12:

Tabel 12. Uji Korelasi Kemandirian Belajar Terhadap Prestasi Belajar

\begin{tabular}{|c|c|c|c|c|c|c|}
\hline Variabel & $\begin{array}{l}\text { Nilai } \mathbf{r} \\
\text { hitung }\end{array}$ & $\begin{array}{l}\text { Sig. }(2- \\
\text { Tailed) }\end{array}$ & $\begin{array}{c}\text { Nilai } \mathbf{r} \\
\text { tabel }\end{array}$ & $\mathbf{N}$ & Df & Keterangan \\
\hline $\begin{array}{l}\text { Hubungan kemandirian belajar } \\
\text { terhadap prestasi belajar }\end{array}$ & 0,730 & 0,000 & 0,433 & 21 & 19 & $\mathrm{H}_{\mathrm{o}}$ ditolak \\
\hline
\end{tabular}


Dari tabel 12 nilai $r$ hitung 0,730 >0,433 dengan nilai Sig. (2-Tailed) 0,000. Dengan demikian $\mathrm{H}_{\mathrm{o}}$ ditolak dan $\mathrm{H}_{\mathrm{a}}$ diterima yang artinya terdapat hubungan antara kemandirian belajar peserta didik dengan prestasi belajar peserta didik dengan tingkat hubungan berada pada kategori kuat karena ada pada interval 0,60-0,799.

\section{Pembahasan}

1. Kemandirian belajar peserta didik kelas eksperimen dan kelas kontrol

Kemandirian belajar peserta didik diukur dari hasil pre test dan post test berupa angket yang telah di uji validitas dan reliabilitasnya dengan jumlah 24 butir pernyataan. Untuk mengetahui kemandirian belajar awal peserta didik peneliti memberikan pre test angket kemandirian belajar baik di kelas eksperimen maupun kelas kelas kontrol. Pre test diberikan sehari sebelum pemberian treatment. Dari hasil pre test yang telah dilakukan menunjukkan bahwa hasil rata-rata pre test kemandirian belajar di kelas eksperimen dengan skala 4 berada pada nilai 2,1 dengan kategori kurang sedangkan untuk kelas kontrol berada pada nilai 2,0 dengan kategori kurang.

Tahap selanjutnya peneliti memberikan treatment berupa penerapan pembelajaran kooperatif tipe STAD di kelas eksperimen. Pada tahap kerja kelompok kemandirian peserta didik dapat dilihat perkembangannya karena dalam proses diskusi kelompok STAD setiap anggota kelompok bertanggungjawab terhadap keberhasilan kelompoknya dan masing masing anggota kelompok harus benar-benar memahami materi yang dibahas, sehingga masing-masing anggota kelompok harus membantu kesulitan anggotanya dan ini memberikan kesempatan pembelajaran tutor sebaya sekaligus menumbuhkan inisiatif peserta didik. Setiap Kelompok diberikan LKS (Lembar Kerja Siswa) atau job sheet dan peserta didik berdiskusi bersama kelompoknya untuk mengerjakan LKS atau job sheet yang telah diberikan dan kemudian wakil kelompok mempresentasikan hasil kerja kelompoknya dan kelompok lainnya memberikan respon berupa pertanyaan atau sanggahan sehingga membuat suasana belajar tidak monoton. Selanjutnya kemandirian belajar peserta didik dapat dilihat perkembangannya pada tahap pemberian kuis, karena pemberian soal kuis individu merupakan bentuk tanggung jawab atas dirinya sendiri maupun kelompok, hal ini disebabkan karena dalam pembelajaran STAD keberhasilan dari masing-masing anggota kelompok akan menentukan keberhasilan kelompoknya sehingga peserta didik lebih percaya diri, tidak bergantung pada orang lain dan dapat menentukan cara belajarnya sendiri. Sedangkan untuk kelas kontrol peneliti memberikan treatment berupa penerapan pembelajaran dengan metode ceramah.

Setelah pemberian treatment selesai peneliti memberikan post test angket kemandirian belajar pada kelas eksperimen dan kelas kontrol. Berdasarkan hasil post test kemandirian belajar peserta didik di kelas eksperimen nilai rata-rata kemandirian belajar peserta didik meningkat menjadi kategori baik dengan nilai rata 3,0 sedangkan pada kelas kontrol nilai rata-ratanya menjadi 2,2 dan masih berada pada kategori kurang. Dari hasil post test kemandirian belajar dapat dilihat perbedaan bahwa kemandirian belajar peserta didik pada kelas eksperimen mengalami perubahan yang sangat baik dibandingkan dengan kelas kontrol. Nilai rata-rata kemandirian belajar peserta didik kelas eksperimen sebelumnya berada di kategori kurang dan setelah diberikan treatment nilai-ratarata kemandirian belajar kelas eksperimen menjadi baik. Sedangkan kelas kontrol dari kategori kurang setelah diberikan treatment nilai-rata-rata kemandirian belajar kelas kontrol tetap berada pada kategori kurang.

2. Prestasi belajar peserta didik kelas eksperimen dan kelas kontrol

Prestasi belajar peserta didik diukur dari hasil pre test dan post test berupa soal pilihan ganda yang terdiri dari 20 soal yang telah di uji validitas dan reliabilitasnya. Untuk mengetahui kemampuan prestasi belajar awal peserta didik peneliti memberikan soal pre test di kelas eksperimen maupun kelas kelas kontrol. Hasil pre test prestasi belajar peserta didik di kelas eksperimen menunjukkan nilai rata-rata 19 yang berada pada kategori sangat kurang, sedangkan di kelas kontrol nilai rata-rata 17 berada pada kategori sangat kurang. Dan dari kedua kelas baik kelas ekseperimen maupun kelas kontrol belum ada peserta didik yang mendapat nilai yang mencapai KKM $=70$ yang artinya tidak ada peserta didik yang mengerjakan secara tuntas.

Pada tahap selanjutnya peneliti memberikan treatment berupa penerapan pembelajaran kooperatif tipe STAD di kelas eksperimen dan metode ceramah di kelas kontrol selama 3 hari berturut-turut. Berdasarkan pada teori slavin [9] salah satu komponen pembelajaran STAD yaitu pemberian kuis, selain bisa untuk mengembangkan kemandirian belajar peserta didik pemberian kuis juga bisa meningkatkan prestasi belajar karena pemberian kuis merupakan sebuah bentuk tanggung jawab secara individual terhadap pemahaman materi yang telah diajarkan oleh guru. Dan pada tahap pemberian reward pada pembelajaran STAD memberikan motivasi kepada peserta didik untuk lebih giat lagi dalam belajar.

Setelah pelaksanaan pembelajaran selesai kemudian peneliti memberikan soal post test pada kelas eksperimen dan kelas kontrol unuk melihat prestasi belajar peserta didik setelah diberikan treatment. Berdasarkan hasil analisis kegiatan post test prestasi belajar peserta didik di kelas eksperimen nilai rata-rata menjadi 71 berada pada kategori baik, dengan pencapaian presentase jumlah peserta didik yang tuntas atau memenuhi KKM sebanyak $67 \%$ dan peserta didik yang tidak tuntas sebanyak 33\%. Sedangkan hasil post test prestasi belajar di kelas kontrol, nilai tertinggi 75 , nilai terendah 30 , dan nilai rata-rata 55 berada pada kategori cukup dengan jumlah peserta didik yang tuntas sebanyak $29 \%$ dan peserta didik yang tidak tuntas sebanyak $71 \%$. Dari hasil post test prestasi belajar dapat dilihat perbedaan bahwa prestasi belajar peserta didik pada kelas eksperimen mengalami peningkatan yang sangat 
baik dibandingkan dengan kelas kontrol, dimana jumlah peserta didik yang tuntas di kelas eksperimen sebanyak $67 \%$ sedangkan di kelas kontrol jumlah peserta didik yang tuntas hanya $29 \%$.

3. Efektivitas penerapan pembelajaran kooperatif tipe Student Teams Achievment Divisions (STAD) terhadap kemandirian belajar pada materi perangkat lunak pengolah angka

Berdasarkan hasil uji hipotesis dengan menggunakan uji t post test angket kemandirian belajar diperoleh nilai $\mathrm{t}$ hitung sebesar 7,953 > t tabel 2,02 dengan nilai signifikansi 0,000, yang artinya $\mathrm{H}_{\mathrm{o}}$ ditolak dan $\mathrm{H}_{\mathrm{a}}$ diterima. Dengan demikian terdapat perbedaan yang signifikan antara hasil post test kemandirian belajar kelas eksperimen dengan hasil post test kemandirian belajar kelas kontrol. Hal ini sekaligus membuktikan bahwa model pembelajaran kooperatif tipe Student Teams Achievment Divisions (STAD) efektif terhadap kemandirian belajar peserta didik pada materi perangkat lunak pengolah angka.

Penelitian yang dilakukan oleh peneliti dikuatkan oleh penelitian terdahulu yaitu yang telah diteliti oleh Wisnu Murti Pratama, Agung Nugroho C.S. dan Bakti Mulyani dalam jurnal yang berjudul Penerapan Metode Pembelajaran Student Teams Achievement Division (STAD) dilengkapi Media Log Book Chesmistry (Logchem) untuk Meningkatkan Kemandirian dan Prestasi Belajar Peserta didik Pada Materi Koloid Kelas KIMIA SMAN 1 Banyudono Tahun Pelajaran 2014/2015. Dari hasil penelitian, maka dapat disimpulkan bahwa: (1) Penerapan metode Student Team Achievement Divisions (STAD) dilengkapi Media Logbook Chemistry (Logchem) dapat meningkatkan kemandirian pada materi koloid. Hal ini dapat dilihat dari kemandirian peserta didik meningkat pada siklus I dan Siklus II. Presentasi kemandirian peserta didik pada siklus I dan II : 39.13\% dan 65,22\%. (2) Penerapan metode Student Team Achievement Divisions (STAD) dilengkapi Media Logbook Chemistry (Logchem) dapat meningkatkan prestasi belajar peserta didik pada materi pokok koloid. Persentase ketuntasan belajar peserta didik adalah $47,83 \%$ pada siklus I dan $82,61 \%$ pada siklus II. Presentasi Capaian Ketuntasan Aspek sikap adalah 26,09\% pada siklus I dan 91,30\% pada siklus II. Capaian untuk aspek keterampilan adalah $100 \%$ [12].

4. Efektivitas penerapan pembelajaran kooperatif tipe Student Teams Achievment Divisions (STAD) terhadap prestasi belajar pada materi perangkat lunak pengolah angka

Hasil penelitian di SMK BPI Baturompe menggunakan analisis data berupa uji hipotesis post test prestasi belajar dengan uji t diperoleh nilai $t$ hitung sebesar 3,990 > t tabel 2,02 dengan nilai signifikansi 0,000, yang artinya $\mathrm{H}_{\mathrm{o}}$ ditolak $\mathrm{H}_{\mathrm{a}}$ diterima. Dengan demikian terdapat perbedaan yang signifikan antara hasil post test prestasi belajar kelas eksperimen dengan hasil post test prestasi belajar kelas kontrol. Hal ini sekaligus membuktikan bahwa model pembelajaran kooperatif tipe STAD efektif terhadap prestasi belajar peserta didik pada materi perangkat lunak pengolah angka.

Penelitian yang dilakukan oleh peneliti dikuatkan oleh penelitian terdahulu yaitu yang telah diteliti oleh Bachren Zaini dan Rizky Swandani dalam jurnal yang berjudul Perbandingan Model Kooperatif Learning Tipe Student Team Achievement Division (STAD) dengan model Kooperatif Learning tipe Numbered Head Together (NHT) terhadap hasil belajar peserta didik pada mata pelajaran Simulasi Digital Kelas X Multimedia di SMK Taruna Bhakti Depok disimpulkan bahwa hasil penelitian yang diterapkan Student Team Achivement Division (STAD) mendapatkan nilai rata-rata 83,98, sedangkan peserta didik yang diterapkan model Kooperatif Learning tipe Numbered Head Together (NHT) mendapatkan nilai rata-rata 78,55, sehingga dapat disimpulkan hasil belajar simulasi digital antara yang diajarkan menggunakan model Student Team Achivement Division (STAD) lebih tinggi dibandingkan dengan yang diajarkan menggunakan model Kooperatif Learning tipe Numbered Head Together (NHT) [2].

5. Hubungan antara kemandirian dan prestasi belajar peserta didik

Berdasarkan hasil analisis uji korelasi diperoleh nilai $r$ hitung $0,730>r$ tabel 0,433 dengan nilai Sig. (2-Tailed) 0,000 . Dengan demikian $\mathrm{H}_{\mathrm{o}}$ ditolak dan $\mathrm{H}_{\mathrm{a}}$ diterima yang artinya terdapat hubungan antara kemandirian belajar peserta didik dengan prestasi belajar peserta didik dengan tingkat hubungan berada pada kategori kuat karena ada pada interval 0,60 - 0,799. Hal ini sekaligus membuktikan bahwa terdapat hubungan antara kemandirian dan prestasi belajar peserta didik.

Penelitian yang dilakukan oleh peneliti dikuatkan oleh penelitian terdahulu yaitu penelitian yang dilakukan oleh Miftaqul Al Fatihah [4] dalam jurnal yang berjudul Hubungan Antara Kemandirian Belajar dengan Prestasi Belajar PAI Siswa Kelas III SDN Panularan Surakarta menyimpulkan bahwa hasil perhitungan Product Moment nilai r hitung adalah 0,581 . Sedangkan nilai $r$ tabel adalah 0,344 , sehingga $r$ hitung $(0,581)>r$ tabel $(0,344)$. Hal ini menunjukkan adanya hubungan kemandirian belajar dengan prestasi belajar PAI siswa kelas III SDN Panularan Surakarta Tahun Ajaran 2015/2016.

\section{KESIMPULAN}

Berdasarkan hasil analisis serta pembahasan mengenai penelitian tentang Efektivitas Pembelajaran Kooperatif Tipe Student Teams Achievement Divisions (STAD) terhadap Kemandirian dan Prestasi Belajar Peserta Didik pada materi Perangkat Lunak Pengolah Angka di SMK BPI Baturompe kota Tasikmalaya maka dapat disimpulkan beberapa hal sebagai berikut : 
1. Kemandirian belajar peserta didik mengalami perkembangan dengan dibuktikan dari nilai rata- rata hasil pre test sebelum diberikan treatment berada pada kategori kurang dan setelah diberikan treatment nilai rata-rata kemandirian belajar peserta didik berada pada kategori baik.

2. Prestasi belajar peserta didik mengalami peningkatan berdasarkan nilai soal pre test dan post test prestasi belajar dimana sebelum diberikan treatment nilai rata- rata peserta didik berada pada kategori sangat kurang dan setelah diberikan treatment nilai rata-rata peserta didik berada pada kategori baik

3. Model pembelajaran kooperatif tipe STAD terbukti efektif terhadap kemandirian belajar. Keberhasilan ini dilihat dari hasil uji t post test angket kemandirian belajar dengan nilai $t$ hitung sebesar 7,953 $>\mathrm{t}$ tabel 2,02 dengan nilai signifikansi 0,000 dimana $\mathrm{H}_{\mathrm{o}}$ ditolak dan $\mathrm{H}_{\mathrm{a}}$ diterima. Dengan demikian rata-rata kelas eksperimen lebih baik dari rata-rata kelas kontrol.

4. Model pembelajaran kooperatif tipe STAD efektif terhadap prestasi belajar ditunjukkan dari hasil uji t post test prestasi belajar diperoleh nilai t hitung sebesar 3,990 > t tabel 2,02 dengan nilai signifikansi 0,000, yang artinya $\mathrm{H}_{\mathrm{o}}$ ditolak $\mathrm{H}_{\mathrm{a}}$ diterima. Dengan demikian rata-rata kelas eksperimen lebih baik dari rata-rata kelas kontrol.

5. Terdapat hubungan antara kemandirian dan prestasi belajar peserta didik dalam mencapai efektivitas. Hal ini terbukti dari uji korelasi antara kemandirian dan prestasi belajar peserta didik dengan nilai $r$ hitung $0,730>r$ tabel 0,433 dengan nilai signifikansi 0,000 dimana $\mathrm{H}_{\mathrm{o}}$ ditolak dan $\mathrm{H}_{\mathrm{a}}$ diterima yang artinya terdapat hubungan antara kemandirian belajar peserta didik dengan prestasi belajar peserta didik dengan tingkat hubungan berada pada kategori kuat.

\section{DAFTAR PUSTAKA}

[1] Arends, R., 2008, Learning to Teach, Yogykarta: Pustaka Belajar.

[2] Bachren Zaini, R. S., 2017, Perbandingan Model Kooperatif Learning Tipe Student Team Achievement Division (STAD) Dengan Model Kooperatif Learning Tipe Numbered Head Together (NHT) Terhadap Hasil Belajar Siswa Pada Mata Pelajaran Simulasi Digital Kelas X Multimedia di SMK Taruna Bhakti, JURNAL PINTER VOL. 1 NO. 1 e-ISSN: 25974475.

[3] Fathurrahman, A., Sumardi, E. Yusuf, A., \& Harijanto, S., 2019, Peningkatan Efektivitas Pembelajaran Melalui Peningkatan Kompetensi Pedagogik dan Teamwork, Jurnal Manajemen.

[4] Fatihah, M. A.,2016, Hubungan Antara Kemandirian Belajar dengan Prestasi Belajar PAI Siswa Kelas III SDN Panularan Surakarta. At-tarbawi, 197-208.

[5] Kristanto, I.,2017,. Skripsi : Penerapan Model Pembelajaran Kooperatif Tipe Student Teams-Achievment Divisions (STAD) Untuk Meningkatkan Hasil Belajar Siswa Pada Mata Pelajaran Teknologi Dasar Otomotif(TDO).

[6] Layinatussifa, I., 2016, Efektivitas Metode Index Card Match dan Metode Ceramah Terhadap Hasil Belajar IPS Kelas VII di SMP Negeri 2 Godean, journal.student.uny.ac.id, 1-11.

[7] Nasution, S., 1996, Pengertian Belajar, Jakarta: Rineka Cipta.

[8] Rachmayani, D., 2014, Penerapan Pembelajaran Reciprocal Teaching Untuk Meningkatkan Kemampuan Komunikasi Matematis dan Kemandirian Belajar Siswa. Jurnal Pendidikan Matematika FIP-UMJ, 13-23.

[9] Slavin, R. E., 2005, Cooperative Learning : Teori, Riset dan Praktik, Bandung: Nusa Media.

[10] Suptiyati., 2013, Upaya Meningkatkan Kemandirian Melalui Layanan Bimbingan Klasikal, Jurnal Ilmiah Pendidikan Bimbingan dan Konseling FIP-IKIP Veteran Semarang, 44-57.

[11] Suryabrata, S., 2002, Psikologi Pendidika, Jakarta: PT. Raja Grafindo Perkasa.

[12] Wisnu Murti Pratama, A. N., 2015, Penerapan Metode Pembelajaran Student Teams Achievement Division (STAD) Dilengkapi Media Log Book Chesmistry (Logchem) Untuk Meningkatkan Kemandirian dan Prestasi Belajar Siswa Pada Materi Koloid Kelas XI MIA SMAN 1 Banyudono Tahun Pelajaran 2014/2015, Jurnal Pendidikan Kimia (JPK), Program Studi Pendidikan Kimia ISSN 2337-9995 Universitas Sebelas Maret.

\section{Biodata Penulis}

Epi Yulistina, memperoleh gelar Sarjana Pendidikan (S,Pd), Program Studi Pendidikan Teknologi Informasi FKIP Universitas Muhammadiyah Tasikmalaya, lulus pada tahun 2020.

Milah Nurkamilah, memperoleh gelar Sarjana Pendidikan (S,Pd), Program Studi Pendidikan Matematika Universitas Siliwangi Tasikmalaya, lulus tahun 2010. Tahun 2016 memperoleh gelar Magister Pendidikan dari Program Studi Pendidikan Matematika Universitas Negeri Yogyakarta. Saat ini menjadi Staf Pengajar Program Studi Pendidikan Teknologi Informasi di Universitas Muhammadiayah Tasikmalaya (UMTAS).

Sulidar Fitri, memperoleh gelar Sarjana Komputer (S.Kom), Program Studi Teknik Informatika STMIK AMIKOM Yogyakarta, lulus tahun 2010. Tahun 2012 memperoleh gelar Magister Science (M.Sc) dari Program Studi Teknik Informatika Asia University Taiwan. Saat ini sebagai Staf Pengajar Program Studi Pendidikan Teknologi Informasi di Universitas Muhammadiayah Tasikmalaya (UMTAS). 